\title{
Minority Threat And Police Strength From 1980 To 2000: A Fixed- Effects Analysis Of Nonlinear And Interactive Effects In Large U.S. Cities
}

\author{
Stephanie L. Kent \\ Cleveland State University, s.l.kent59@csuohio.edu \\ David Jacobs \\ Ohio State University, JACOBS.184@OSU.EDU
}

Follow this and additional works at: https://engagedscholarship.csuohio.edu/clsoc_crim_facpub

Part of the Criminology and Criminal Justice Commons, Sociology Commons, and the Urban Studies and Planning Commons

How does access to this work benefit you? Let us know!

Publisher's Statement

(c) 2005 American Society of Criminology

\section{Repository Citation}

Kent, Stephanie L. and Jacobs, David, "Minority Threat And Police Strength From 1980 To 2000: A FixedEffects Analysis Of Nonlinear And Interactive Effects In Large U.S. Cities" (2005). Sociology \& Criminology Faculty Publications. 113.

https://engagedscholarship.csuohio.edu/clsoc_crim_facpub/113 


\title{
MINORITY THREAT AND POLICE STRENGTH FROM 1980 TO 2000: A FIXED-EFFECTS ANALYSIS OF NONLINEAR AND INTERACTIVE EFFECTS IN LARGE U.S. CITIES*
}

\author{
STEPHANIE L. KENT \\ University of Nevada, Las Vegas \\ DAVID JACOBS \\ Ohio State University
}

KEYWORDS: minority threat, police per capita, city level trends, interactions, nonlinear relationships

Many studies have assessed threat theory by investigating the relationships between the size of minority populations and police strength. Yet these investigations analyzed older data with crosssectional designs. This study uses a fixed-effects panel design to detect nonlinear and interactive relationships between minority presence and the per capita number of police in large U.S. cities in the last three census years. The findings show that the relationship between racial threat and the population-corrected number of police officers has recently become considerably stronger. In accord with theoretically based expectations, tests for interactions show that segregated cities with larger African American populations have smaller departments. The coefficients on another interaction effect suggest that racial segregation leads to reductions in police strength in the South perhaps because officers are less likely to intervene in residentially isolated black neighborhoods in this region.

The authors are grateful to the NSF (Grant \# SES-0417736) for partial support for this project, to the editor for his patience, and to Brian Stultz for supplying his data on residential segregation. All data used in these analyses are available on request. Comments regarding this paper should be addressed to David Jacobs, Department of Sociology, 300 Bricker, 190 North Oval Mall, Ohio State University, Columbus, $\mathrm{OH} 43210$. 
What is the relationship between the presence of racial minorities in large U.S. cities and the strength of police departments, and how does this relationship fluctuate over time? In comparison to other nations, race relations throughout U.S. history have been exceptionally antagonistic and violent (de Tocqueville, 1835/1948; Myrdal, 1944), and this racial violence was not confined to the civil war that occurred almost 150 years ago. Immediately after that war and for more than 80 years following, vigilantes lynched blacks to maintain a racial caste system (Tolnay and Beck, 1996). More recently, the conventional public wisdom has viewed urban violence as almost entirely due to racial and ethnic minorities (Chiricos, Welch and Gertz, 2004). Multiple findings suggest that majority whites, apparently threatened by the presence of large minority populations (Fosset and Kiecolt, 1989; Taylor, 1998), often make successful political demands for additional police officers in cities with the most minority residents (Jacobs, 1979, Liska, Lawrence and Bensen, 1981; Jackson, 1989).

Some characteristics of police work help explain why this independent relationship is often reported. Due to chronic uncertainties, the behavior of officers on the street is primarily reactive rather than proactive (Wilson, 1971; Rubenstein, 1973; Ericson, 1982, 1989). Police officers are not abundant in relation to the populations they must control (Sherman, 1992). Because officers cannot read minds nor see into buildings, they find it difficult to identify recent law breakers or those who are about to commit such acts (Rubenstein, 1973; Ericson, 1982, 1989). Choices about who to stop must be made on the basis of anomalies and crude decision rules (Weitzer and Tuch, 2002; Lundman and Kaufman, 2003). These decisions, because they are based on group rather than individual characteristics, often result in statistical discrimination (Rubenstein, 1973; Ericson, 1982, 1989). Officers also face special handicaps in underclass neighborhoods because street criminals and the innocent share many characteristics in such districts.

But if the police are particularly numerous relative to a city's population, their reliance on anomalies should make them more effective in white neighborhoods, where residents tend to be visibly distinct from minority street criminals (Jacobs, 1979; Manning, 1994). Even if the police do not make unwarranted efforts to please whites, whites should benefit from larger departments. It is plausible that the geographic boundaries insulating white neighborhoods from underclass street criminals should be less permeable in cities with a higher ratio of officers. This logic suggests that additional officers should be present in communities when white anxieties about crime are magnified by substantial minority populations (Liska, Lawrence and Sanchirico, 1982; Quillian and Pager, 2001). Yet the studies that tested this relationship suffered from some important 
difficulties that we hope to correct with a pooled time-series research design.

Multiple studies have assessed the relationship between racial or ethnic minorities and police strength (Jacobs, 1979; Liska et al., 1981; Jackson, 1989), yet almost all were cross-sectional. Shifts in the strength of the association between minority presence and the number of police officers could not be detected. Greenberg, Kessler and Loftin (1985) used a panel design, but they entered explanatory variables from the previous census to account for police strength a decade later. Such a long lag is implausible: it should not take ten years for these relationships to be completed. Greenberg and his colleagues included a lagged dependent variable on the right side of their models, yet both correlated measurement error between the dependent variable and its lag and serial correlation weakened the coefficients on the other explanatory variables. Most of the cities in the Greenberg sample were smaller than those in studies finding greater support for racial threat. This reduced support is not surprising, given that the literature suggests that informal control is more effective in small cities. Racially threatened whites therefore have greater reasons to demand additional police officers in the larger cities analyzed in most of the literature. Although race mattered in only some of their analyses, methodological problems suggest that the Greenberg findings should be reexamined.

The literature has additional gaps. Despite some of the implications of threat theory, few tests for interactive relationships have been conducted, and there may be problems with omitted variable bias. We have not located studies that analyzed data after 1990. In the absence of such studies we do not know if the association between minority presence and police strength persists or if it has recently become stronger. In contrast to the Greenberg et al. study, we use a less questionable pooled time-series, fixed-effects approach to disentangle the interactive, nonlinear and fluctuating relationships between African American or Hispanic presence and the population corrected number of police officers in U.S. cities in the last three census years. ${ }^{1}$ Although we test hypotheses derived from other

1. In comparison to cross-sectional approaches, pooled time-series cross-sectional alternatives offer multiple benefits. The combination of multiple cross-sections expands the number of cases. One result is that variable variance is increased and multicollinearity typically is reduced in such designs. In comparison to pure crosssectional research designs, pooled time-series cross-sectional approaches therefore offer increased statistical power and all of the other inferential benefits that come with larger samples. And the fixed-effects procedure that can be used in pooled designs provides an effective way to reduce problems with omitted variable bias that plague non experimental research. In addition to these advantages, controls for period let researchers test for time-specific interactions. Such specifications can uncover historically contingent relationships by detecting associations between 
theoretical perspectives, our primary goal is to provide superior tests of refinements to the racial threat version of conflict theory.

\section{THEORETICAL EXPLANATIONS}

\section{MINORITY THREAT}

Racial fissures once were and probably still are the most important social and political division in the United States. These schisms may explain alterations in law and order measures such as the number of police officers in large cities, because the threat posed by comparatively substantial minority groups should produce increasingly severe measures against street crime. Both sociologists and political scientists have provided the conceptual foundation for this threat account (Key, 1949; Blumer, 1958; Blalock, 1967; Bobo and Hutchings, 1996). Ethnocentric beliefs and dominant group tendencies to view minorities as interlopers strengthen dominant group presumptions that they should have exclusive claims over important rights and privileges (Bobo and Hutchings, 1996). Majority groups' entrenched beliefs about their "rightful" position and their unfavorable opinions about minorities emerge from the political struggles that occur when minorities seek more equitable distributions (Blumer, 1958). Larger minority populations jeopardize the political and cultural ascendancy of majority groups, who frequently react by supporting political measures that are designed to help them maintain their privileged position.

This presence of hostile views about minorities provides one of the conceptual links between the threat posed by large minority populations and law and order outcomes. Negative opinions about blacks are more likely in areas with larger black populations (Fosset and Kiecolt, 1989; Taylor, 1998). As one might expect, relatively substantial minority populations produce increased white votes for anti-minority candidates (Giles and Buckner, 1993; Giles and Hertz, 1994). Findings also show that majority whites express greater anxieties about criminal victimization in communities with more black residents. With crime rates held constant, both Liska et al. (1982) and Quillian and Pager (2001) find independent positive relationships between the percentage of blacks in cities or in neighborhoods and fear of crime.

In light of these results, it should not be surprising that multiple studies support the next link in this causal chain by suggesting that the anxieties and resentments that arise from minority threat lead dominant ethnic

explanatory and dependent variables that differ in strength by period (see Kennedy, 2003 for a more extensive discussion of these and other benefits). 
groups to pressure political authorities to make greater efforts to control street crime. A longitudinal analysis suggests that growth in the presence of nonwhites leads to subsequent increases in spending on prisons and jails (Jacobs and Helms, 1999). Jacobs and Carmichael (2001) use fixed-effects estimation and find that U.S. states with the most substantial African American and Hispanic populations have higher imprisonment rates. Such results and the repeated cross-sectional findings showing that cities with large minority populations either have more police officers relative to their population (Jacobs, 1979; Huff and Stahure, 1980; Liska et al., 1981) or spend larger amounts on the police (Jackson and Carroll, 1981; Jackson, 1989) combine to suggest that: The per capita number of police officers will be greater in cities with the most substantial percentages of black residents. In some cities Hispanics are largest underclass minority, so the same logic leads to an expectation that: The per capita number of police officers will be greater in cities with the largest percentage of Hispanic residents.

But the relationship between Hispanic presence and police size may not be linear. In many cities outside the southwest, the percentage of Hispanics is extremely modest. The median percentage in our sample, for example, was 4.9 percent but the median percentage of blacks was 20.9 percent. Because the Hispanic population was so small in so many cities, it is plausible that this minority must reach a threshold size before majority whites consider this group as sufficiently threatening. We therefore predict that: the nonlinear relationship between the percentage of Hispanic residents and the per capita number of police officers should become positive after the relative size of this ethnic minority reaches a level that threatens majority whites.

Yet the relationships between minority threat due to larger black populations and law enforcement strength may not be additive. Social outcomes often depend on the joint appearance of more than one set of conditions that each of must be present in sufficient strength. Another implication of threat theory can be assessed by assessing the interactive effects of residential segregation. We start with the additive component by hypothesizing that: whites should not feel as menaced by larger black populations when residential segregation is pronounced. We thus expect that enhanced residential separations between the races should reduce the population-corrected police presence, but this relationship may be present only in cities with relatively large African American populations.

Racial threat theory therefore suggests an interactive relationship between percentage of African Americans and residential segregation, particularly if police departments are less likely to interfere in black affairs when this minority is isolated from whites. Studies suggest that segregation reduces racial threat because relatively separated neighborhoods make blacks less threatening to whites. This residential isolation lowers arrest 
probabilities (Stolzenberg, D'Alessio and Eitle, 2004; Liska, Chamlin and Read, 1985; Liska and Chamlin, 1984) in part because segregation reduces white victimization by African American street criminals (Liska and Chamlin, 1984). Such declines in white victimization should alleviate white pressure on political authorities to do something about crimes committed by blacks (Stolzenberg et al., 2004: 676). If this logic is correct and departments are not likely to police ghetto neighborhoods as vigorously when residential segregation is pronounced, the most racially segregated cities need not have as many officers as their less segregated counterparts. With main effects held constant we therefore expect that: when residential segregation and the percentage of blacks are both substantial, the per capita number of police officers should be reduced. This proposition implies that the coefficient on an interaction term based on the product of residential segregation and city percentages of African Americans should be negative.

Another contingent relationship is equally plausible. James Q. Wilson (1971: 141) talks about police departments that avoid enforcing the law, particularly in minority neighborhoods, unless behavior in such neighborhoods offends high-status whites. The police in these cities assume that blacks both want and deserve "less law enforcement because to the police their conduct suggests a low level of private morality, an unwillingness to cooperate with the police or offer information, and widespread criminality." Such departments largely ignore African Americans "because they have no influence and their conduct, except within broad limits is not thought to be self regulating" (141).

Such views should be most common in the South. It seems likely as well that a policy of reduced law enforcement in the ghetto should be least offensive to high-status whites when residential segregation is most intense and whites have less contact with blacks. Because departments that avoid intervening in the ghetto need not be as large as their counterparts that vigorously police the ghetto, the most residentially segregated cities in the South should therefore have fewer police officers. This hypothesis suggests that the coefficient on an interaction term calculated on the product of residential segregation and location in the South should also be negative. It follows that a larger African American presence ought to produce additional police officers, but racially segregated southern cities or highly segregated cities with the most black residents should have fewer officers relative to their population.

Finally, the pooled time-series approach we use in this analysis can address another important issue. Due in part to the increased emphasis on the racial aspects of departures from law and order in political campaigns during the period at issue (Edsal and Edsal, 1991; Beckett, 1997; Stucky, Heimer and Lang, 2005), perhaps the magnitude of the association 
between racial threat and police strength has increased. According to Beckett, increases in strident political claims about street crime during this period enhanced the public salience of the racial aspects of law and order and contributed to enhanced resentments against black street criminals (1997). Findings support such claims as indicators of the political strength of the political party that emphasized law and order and minority presence became stronger predictors of imprisonment rates in the states during this period (Jacobs and Carmichael, 2001). To gauge equivalent shifts in the intensity of the relationship between minority presence and police strength, we enter interactions between African American presence and period. If the association between racial threat and police strength became more substantial from 1980 to 2000, we can expect to find positive coefficients on interaction terms calculated with the product of the percentage of blacks and the dummy variables we use to capture otherwise unmeasured period effects on police strength.

\section{ALTERNATIVE EXPLANATIONS}

\section{POLITICAL ACCOUNTS}

Spending on police departments represents a substantial share of municipal revenues, so political explanations should matter. Although city-level political measures are not abundant, one institutional arrangement ought to be influential. In the early part of the 20th century, government by unelected city manager was championed by upper middle class progressives who sought to depoliticize municipal administration and reduce the power of the urban political machines supported by new immigrants from eastern and southern Europe. Progressives claimed that appointed managers-who would not be subject to the whims of unsophisticated voters or induced to win their votes with corrupt practices - would be more likely to make efficient decisions. One analysis suggests that the process we study is at least partially political as expansions in police employees are greater in local election years (Levitt, 1997). Another finds that municipalities with a city manager are dominated by well-educated citizens (Jacobs and O'Brien, 1998). Such upper middle class communities should be less responsive to racially motivated public demands for law and order. And city administrators who do not face the voters can better resist media driven panics about street crime and the resulting public pressures to hire additional but unnecessary officers. For these reasons, we expect fewer police officers in cities with a city manager. 


\section{SOCIAL DISORGANIZATION}

Garland claims that enhanced public demands for law and order are produced by social disorganization (2000). This condition may account for stronger police departments after crime rates have been held constant. Some violence and other threatening acts that result from social disorganization may not be captured by the crime rates, but these unruly acts may lead to enhanced public anxieties and added political pressure to hire more officers (Tyler and Boeckman, 1997; Garland, 2001). Holding such factors constant is important because jurisdictions with larger minority populations may hire new law enforcement personnel, but not necessarily due to minority threat. Instead, public anxieties and resentments arising from social disorganization are likely to appear in cities where underclass minority populations are most substantial. If disorganization effects are not held constant, we could not rule out the possibility that citizens, when they successfully pressure political authorities to hire more officers, are responding to the unruly acts due to social disorganization rather than to minority threat. These considerations suggest that cities with larger percentages of families below the poverty line or with higher divorce rates will have more officers. Divorce rates should be especially influential because the police often must intervene in violent domestic disputes, but this relationship may not be linear because these rates may only produce additional police officers after a threshold in these rates is reached. To capture another dimension of social disorganization, we hold constant crowding or the proportion of dwelling units with more than 1.01 persons per room.

\section{ADDITIONAL EXPLANATIONS}

Police services represent a significant drain on municipal budgets. Because police work is labor intensive, at least 80 percent of department funds are spent on officer wages. It follows that the number of officers

should partly depend on the tax base. In this study we do not use the department percentage of city revenues to capture this effect. Although city governments can decide to increase taxes in order to hire additional officers, such decisions are constrained by the resources available to be taxed. The point is that if political demands for expansions in the number of officers are sufficiently intense, cities could secure the necessary revenue by increasing taxes, but the proportion of city revenues spent on law enforcement could remain constant. The resources that can be taxed, however, ultimately depend on resident incomes. We deliberately assess actual resource constraints using city income levels rather than the more discretionary proportion of city revenues spent on the police. 
Studies of criminal punishment have repeatedly focused on the neoMarxist hypothesis that punishment is used to control the excess supply of labor in capitalist societies (Rusche and Kirchheimer, 1939). Many investigations assessed the link between unemployment and incarceration, but the results have been inconclusive. A literature review, for example, shows that only about 60 percent of the 147 associations between unemployment and imprisonments are significant and positive (Chiricos and Delone, 1992). In spite of such mixed findings, it is reasonable to expect that high joblessness rates will produce expansions in police officers because high status politically influential citizens may view the unemployed as a threat to social order (Chambliss, 1964) or because substantial unemployment leads to resentments against underclass criminals and thus magnifies public demands for additional law enforcement capacity.

It is important to examine the explanatory power of city size because the likelihood of successfully identifying criminal offenders is enhanced in the smallest cities (Jackson, 1984; Mayhew and Levinger, 1976). The resulting enforcement difficulties in large municipalities suggest that departments should have more officers relative to their population in the most populous communities. Finally, because the number of officers should be greater in cities with higher crime rates, we examine the explanatory power of the property and the violent crime rates. But many of these crimes may not be important enough to influence police strength. Because the far more serious homicides should produce greater anxieties, the murder rates rather than the violent or the property crime rates should be included in the models as well. The homicide rates are measured with greater accuracy than the other index crimes reported in the Uniform Crime Reports (UCRs), but these rates may have a nonlinear relationship with the number of police officers. Perhaps, after these rates have gone past a threshold, additional homicides will substantially enhance the probability of successful public demands for additional officers.

\section{METHODOLOGY}

\section{SAMPLE}

Due to severe limits on data availability in off census years, we analyze the determinants of police strength in 1980, 1990 and 2000 in U.S. cities that had populations greater than 100,000 in 1980. Using separated periods in a pooled time-series analysis is advantageous because such a sampling procedure reduces serial correlation and the effects of measurement error (Johnston and DiNardo, 1997). Pooled time-series cross-sectional estimators are robust to shifts in the number of cases included in different 
periods (Johnston and DiNardo, 1997; Wooldridge 2002), but in this instance few such differences are present. The number of cities included in this analysis in 1980 and in 1990 is 125 , but falls to 123 in the 2000 crosssection, leaving 373 city-years in all analyses.

\section{ESTIMATION}

In contrast to the random-effects approach used in most panel analyses in criminology, the fixed-effects alternative holds constant any unchanging case attributes by (in effect) entering separate dummy variables for each city. This makes fixed-effects estimates unbiased when unmeasured timeinvariant city characteristics associated with the explanatory variables influence the dependent variable. In comparison to random-effects, stronger claims can be made that omitted variables are not distorting such estimates (Johnston and DiNardo, 1997; Wooldridge, 2002; see Kennedy, 2003 for an enumeration of additional statistical advantages). These casespecific dummy variables used in fixed-effects analyses represent different intercepts for each city. Such city-specific intercepts will capture any unchanging city differences in the number of police officers that are idiosyncratic. For instance, regional effects are automatically held constant in fixed-effects models. We also control for otherwise unmeasured period shocks that may have influenced police strength in many cities by including time-specific dummy variables in the models (for precedent, see Eitle, D'Alessio and Stolzenberg, 2002; Kent and Jacobs, 2004). The relationships at issue therefore will be estimated with two-way fixedeffects models in part because Hausman tests indicate that fixed-effects and random-effects estimates differ significantly.

\section{MEASUREMENT}

We measure racial threat with the natural $\log$ of the percentage of African Americans (some variables are in natural $\log$ form to reduce outliers and heteroskedasticity). Ethnic threat is measured with the percentage of Hispanics. ${ }^{2}$ Residential segregation is assessed with the index of dissimilarity based on the odds that any black will come into contact with any white. City manager presence is captured with a dummy variable coded 1 for cities with this arrangement. We gauge the tax base with real (corrected for inflation) median family income, and include the

2. Because Hispanics are concentrated in the Southwest, in this paper we emphasize racial rather than Hispanic threat. Although this analysis of all large cities will provide some theoretically interesting findings about Hispanic threat, a study that focuses on the menace of Hispanics probably should be restricted to a sample of large cities in the Southwest and in the West. 
natural log of FBI violent and property crime rates in some models and the murder rates and their square in others. We measure social disorganization with percentage divorced, the natural $\log$ of the percentage of families with incomes below the poverty line, and the natural $\log$ of the percentage of dwelling units with more than 1.01 persons per room. ${ }^{3}$ Population is included in these models to capture the independent effects of city size.

Period effects that may influence department strength across all cities in a particular year are held constant by including two dummy variables coded 1 for 1990 and for 2000. To assess the degree to which the relationship between the percentage of blacks and police strength fluctuates, in some models we include two interaction terms calculated with the products of the two period dummy variables and the percentage of African Americans. We expect that the racial threat relationship has become stronger, so the coefficients on these two interaction terms should be positive. Recall that additional interaction terms include the product of the percentage of blacks and racial segregation along with the product of racial segregation and a dummy variable coded 1 for southern cities. All required main effects are entered in models that assess the explanatory power of interactions. ${ }^{4}$

The percentage of African Americans and the segregation rates are mean centered before they are multiplied to create the interaction terms. In models that gauge interaction effects, the coefficient on a mean centered main effect represents this variable's additive contribution when the alternative mean centered main effect is equal to its mean. If mean centering is not used, the coefficient on each main effect depicts the additive relationship between that main effect and the dependent variable when the value of the alternative main effect is equal to zero. In addition

3. We include the percentage below the poverty line in part because measures of income inequality are not available (the census stopped supplying the Gini index for cities after 1980). City scores on the Gini index, however, are closely associated with the percentage below the poverty line as findings suggest that most of the variation in the Gini index is due to the gap between lower and middle income recipients (Jacobs 1980).

4. To produce the most accurate results, we follow the advice of econometricians and include many controls in the models. For example, Johnston says "it is more serious to omit relevant variables than to include irrelevant variables since in the former case the coefficients will be biased, the disturbance variance overestimated, and conventional inference procedures rendered invalid, while in the latter case the coefficients will be unbiased, the disturbance variance properly estimated, and the inference procedures properly estimated. This constitutes a fairly strong case for including rather than excluding relevant variables in equations. There is, however, a qualification. Adding extra variables, be they relevant or irrelevant, will lower the precision of estimation of the relevant coefficients" (1984: 262). Inclusive specifications thus tend to produce more conservative significance tests. 
to its contribution to clarity, centering is methodologically useful as it helps to reduce collinearity between main effects and the interaction term (Cohen, Cohen, West and Aiken, 2003).

We follow past researchers and measure the dependent variable with the number of sworn police officers per 100,000 population (Jacobs, 1979). To provide time for the relationships in question to be completed, the number of officers is measured in the year after a decennial census. This variable also is in natural log form to reduce problems with outliers and heteroskedasticity.

\title{
SPECIFICATION
}

Theoretical considerations suggest that, except for the negative relationship we expect between city managers and police strength, the coefficients on all remaining linear effects save those not theorized should be positive. We expect that the percentage of Hispanics, the divorce rate, and the murder rates will only produce additional police officers after these factors reach levels that produce enhanced demands for law and order. If expansions after an inflection point produce increased police strength, the coefficients on the square of these three variables should be positive.

A general specification of these fixed-effects models is:

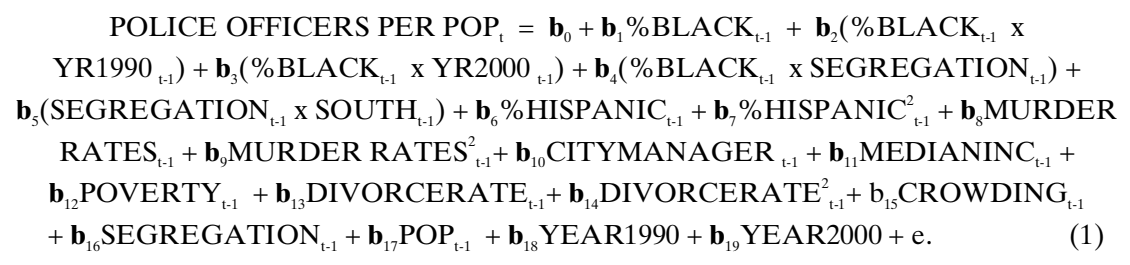

with all variables defined as above. Because regional effects are captured by the city specific dummy variables (whose coefficients will not be shown in the tables), the required main effects are represented by $b_{1}, b_{16}, b_{18}$, and $b_{19}$. Because we predict signs, all significance tests save those on the period dummies and the intercepts are one-tailed.

\begin{abstract}
ANALYSES

\section{DESCRIPTIVE STATISTICS AND CROSS-TABULATION}

Table 1 shows the expected signs, the variable means, and their standard deviations. The per capita number of police officers in these cities has grown in each of the three periods we analyze. In 1981 this mean was 216.2 officers per 100,000 population, yet by 1991 it had risen to 230.6
\end{abstract}


and by 2001 to 255.6 . Officers per 100,000 city residents ranged from 108.5 in Anchorage, Alaska in 1991 to 756.8 in Washington, DC in the same year. An inspection of these rankings suggests that smaller, socially homogeneous communities have the fewest officers relative to their populations, but the large, racially diverse older cities seem to have the most. ${ }^{5}$ To provide an intuitive picture of how police strength covaries with three important explanatory variables, Table 2 shows mean police strength cross-classified by the percentage of African Americans, the percentage of Hispanics and by the presence of a city manager. Relevant comparisons always support our expectations about race as all cell means increase in rows with larger percentages of African Americans. But these contrasts imply that Hispanic presence may not have as much explanatory power as race. Compared to cities without a city manager, mean officers are substantially reduced if cities have this political arrangement. These simple comparisons may not persist after many additional factors are held constant in the fixed-effects analyses, but they nevertheless imply that some of our most important suppositions are correct. The correlation matrix presented in Table 3 shows that these associations are relatively modest.

\begin{tabular}{lcrr}
\hline $\begin{array}{c}\text { Table 1. Predicted Signs, Means, and Standard Deviations } \\
\text { (N = 373 city-years) }\end{array}$ & & \\
Variable & Prediction & Mean & \multicolumn{1}{c}{$S D$} \\
Ln police per 100,000 & & 5.394 & .341 \\
Ln \% black & + & 2.773 & 1.021 \\
Segregation rate & + & 59.852 & 14.521 \\
\% Hispanic & + & 11.197 & 13.941 \\
\% unemployed & + & 1.795 & .443 \\
Real median income & + & 414.018 & 79.402 \\
1 if city manager & - & .424 & .495 \\
\% divorced & + & 10.680 & 2.190 \\
Murder rate & + & 16.134 & 12.827 \\
Ln \% poverty & + & 2.537 & .396 \\
Ln crowding & + & 1.556 & .605 \\
Population per 100,000 & + & 4.287 & 7.816 \\
\hline
\end{tabular}

5. Socially homogeneous cities with the fewest officers per 100,000 include Fresno CA (114.2 in 1990), Modesto CA (117.8 in 1980), Anaheim CA (121.5 in 2000), and Eugene OR (123.5 in 2000). Cities with the most included Baltimore MD (507.5 in 2000), Honolulu HI (517.3 in 2000), Las Vegas NV (533.3 in 1980), and Washington DC (630.5 in 2000). Other older large cities such as New York and Chicago had comparatively large police departments as well. 
Table 2. Mean Police Officers per 100,000 Cross-Classified

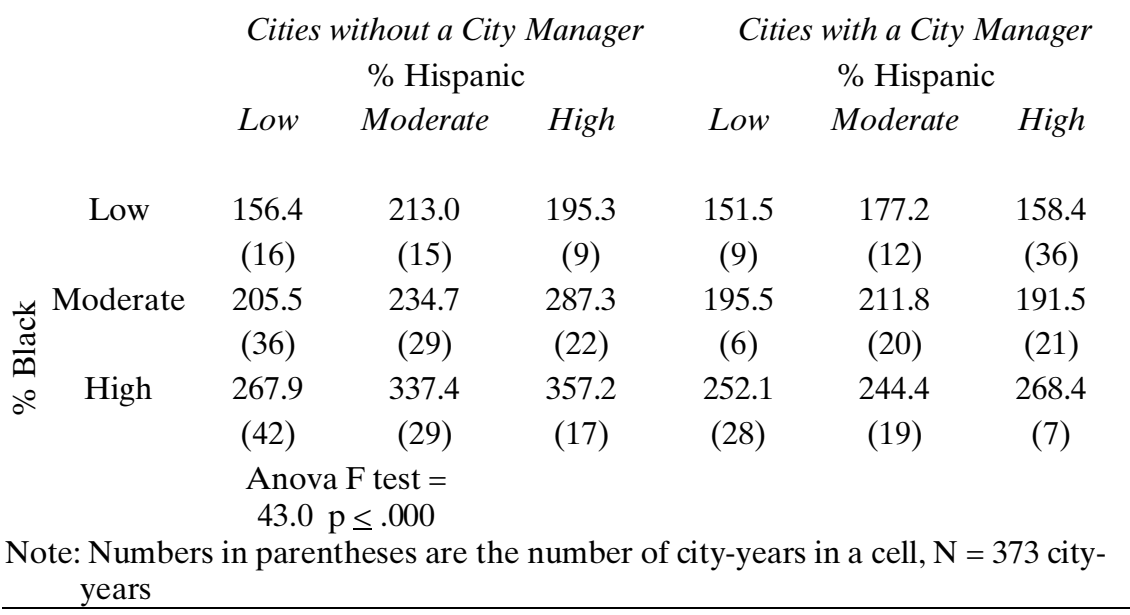

\section{FIXED-EFFECTS RESULTS}

To facilitate comparisons, we begin with a basic specification presented in Model 1 in Table 4. Although racial effects are included in the first model, we (temporarily) ignore nonlinear and interaction effects. In Model 2 we enter interactions between period and the percentage of African Americans to discover whether the relationship between racial threat and police strength has shifted in the last two decades. Recall that this test is conducted by multiplying the 1990 and 2000 period dummy variables by the percentage of blacks. If the coefficients on these two interaction terms are significant with the main effects held constant, we can conclude that the magnitude of this racial threat relationship has expanded or contracted in that period. In this model we also introduce Hispanic presence and its square along with a similar quadratic test of divorce rate effects to capture nonlinear relationships. In Model 3 in Table 4 we add the property and the violent crime rates to the explanatory variables included in Model 2.

The results in Model 1 suggest that the most residentially segregated cities with higher unemployment rates have more police officers relative to their populations. As expected, however, city manager presence leads to reductions in police strength. Yet absent tests for period specific interactions, the presence of blacks has no effect on this outcome. The significance tests on the two period-specific dummy variables indicate that there is sufficient overtime variation in the dependent variable to estimate with fixed-effects. 


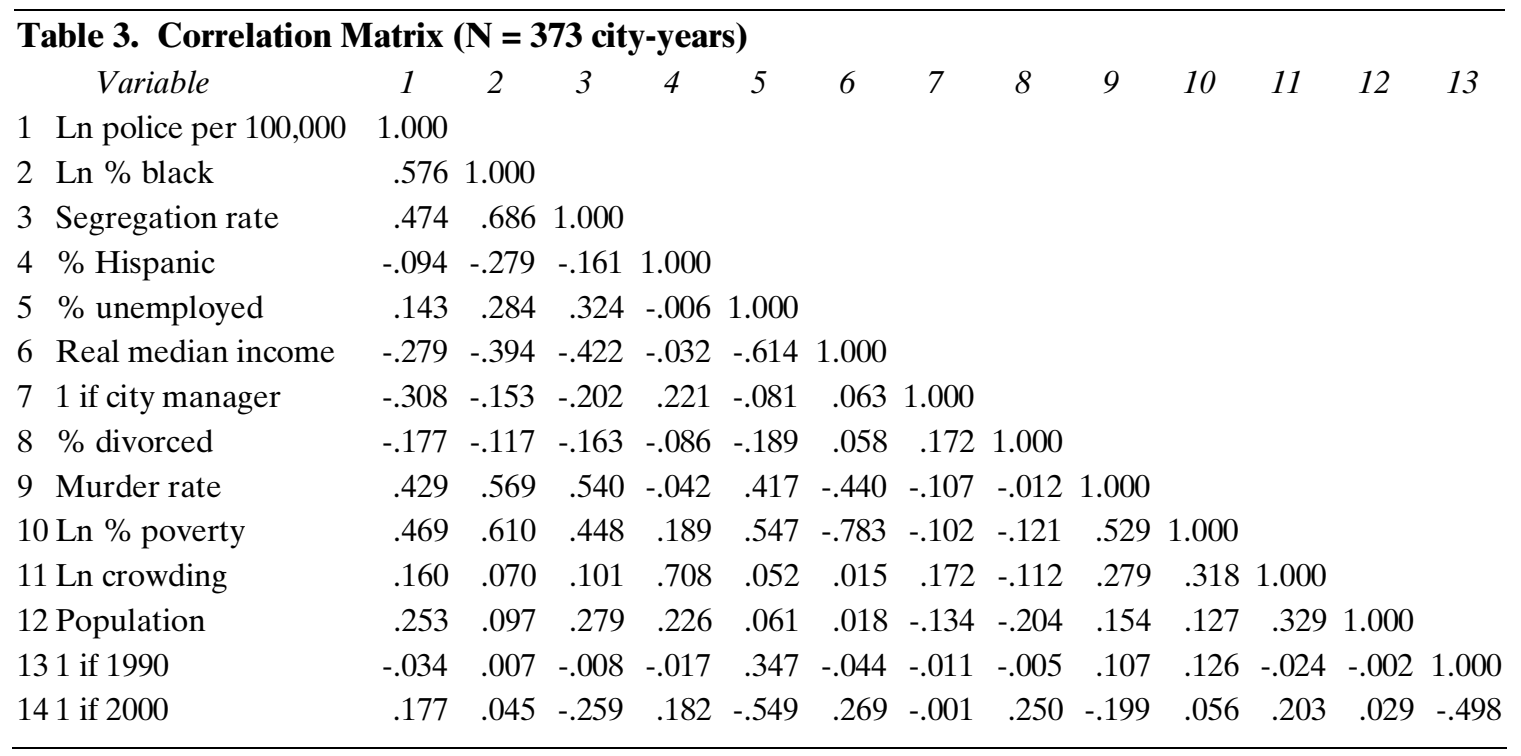




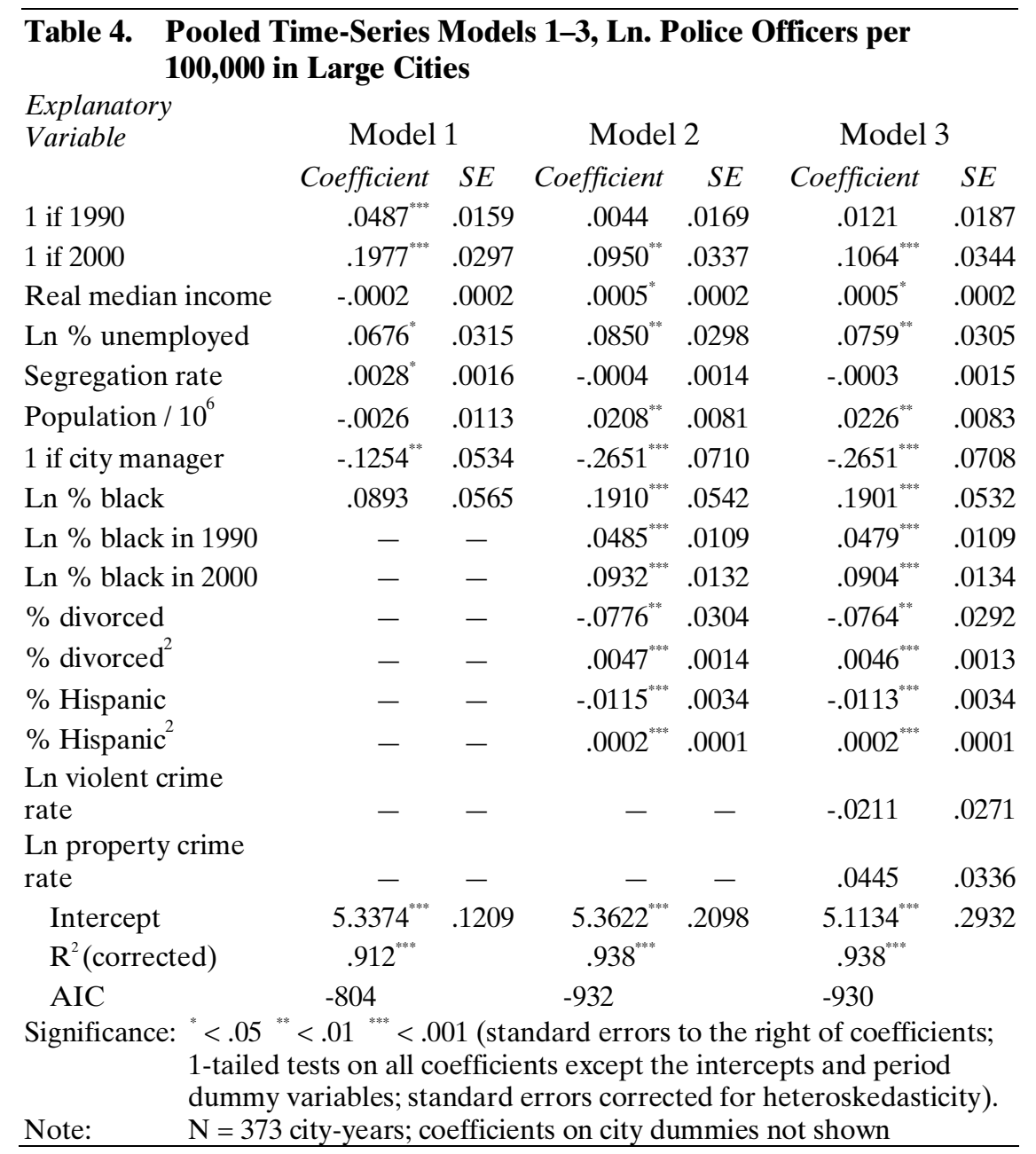

In Model 2 we find that the percentage of Hispanics, and the divorce rate have nonlinear relationships with the dependent variable. As expected, both variables must reach thresholds before police strength starts to expand (we defer reporting inflection points until the discussion of the best model.) But the most important contrast between Model 1 and Model 2 concerns racial effects. When the coefficient on the percentage of blacks is not forced to be identical in different periods, the explanatory power of racial threat sharply increases. These interactions between racial threat and period suggest that the association between black presence and police strength became stronger in both 1990 and 2000. The reduction in 
the Akaike Information Criterion (AIC) score for Model 2 suggests that this specification has much greater explanatory power than the specification used in Model 1. In the last model in Table 4, we add the property and violent crime rates, but the results show that although the explanatory variables that were significant in Model 2 continue to matter, neither of these perhaps overly aggregated crime rates explains police strength.

We still need to discover whether other interaction effects influence police department strength. Theory suggests that the number of officers should differ in segregated cities with larger percentages of blacks or in segregated cities in the South. In light of the weak influence of the aggregated crime rates, we also should use the murder rates in place of these combined rates. In Model 4 in Table 5 we start by entering an interaction between residential segregation and the percentage of blacks and we replace the aggregated crime rates with the murder rates and their square. In Model 5 we add an interaction between residential segregation and city location in the South. Recall from the theoretical discussion that residentially segregated cities with larger black populations should need fewer officers if racial separation reduces black threat. The same prediction about police strength reductions should hold when the interaction between residential segregation and city location in the South is assessed. Finally, in Model 6 we add crowding and the poverty rates to capture otherwise unmeasured social disorganization effects.

The findings in Model 4 suggest that expansions in the murder rates explain police strength, but the murder rates do not produce additional officers until they reach a threshold. The coefficient on the interaction between the percentage of black residents and residential segregation supports a supposition that the most racially segregated cities with the largest black populations are likely to have fewer police officers relative to their population. After we add the interaction between residential segregation and location in the South in Model 5, we find strong evidence that residential separation between the races reduces police strength in this region. The substantial reduction in the AIC statistic suggests that the inclusion of this interaction term produces a sizeable increase in model explanatory power. Finally in Model 6 in Table 5, we add the percentage of families below the poverty line and the percentage of dwelling units with more than 1.01 persons per room, but the results suggest that these indicators of social disorganization have no effects on police strength.

We use the point estimates from the best model (see Model 5 in Table $5)$ to calculate the inflection points for the quadratic specifications and find that the percentage of Hispanics in a city must grow to about 25.4 percent or more than five times its median (or 4.9 percent) before the per capita number of officers starts to expand due to increases in this minority population. This result suggests that the percentage of Hispanics must go 


\begin{tabular}{|c|c|c|c|c|c|c|}
\hline & \multicolumn{2}{|c|}{ Model 4} & \multicolumn{2}{|c|}{ Model 5} & \multicolumn{2}{|c|}{ Model 6} \\
\hline & Coefficient & $S E$ & Coefficient & $S E$ & Coefficient & $S E$ \\
\hline 1 if 1990 & .0147 & .0168 & .0081 & .0158 & .0085 & .0213 \\
\hline 1 if 2000 & $.1294^{* * * * *}$ & .0327 & $.1089^{* * * *}$ & .0319 & $.1124^{* *}$ & .0387 \\
\hline Real median income & $.0004^{*}$ & .0002 & $.0004^{*}$ & .0002 & .0004 & .0003 \\
\hline Ln \% unemployed & $.0961^{* * * * *}$ & .0292 & $.0786^{* *}$ & .0296 & $.0822^{* *}$ & .0311 \\
\hline Segregation rate & .0006 & .0015 & $.0025^{*}$ & .0012 & $.0028^{*}$ & .0014 \\
\hline Population / $10^{6}$ & $.0189^{*}$ & .0087 & $.0185^{*}$ & .0081 & $.0195^{* * *}$ & .0082 \\
\hline 1 if city manager & $-.1924^{* *}$ & .0797 & $-.1616^{* *}$ & .0630 & $-.1629^{* *}$ & .0660 \\
\hline Ln \% black & $.1381^{* *}$ & .0523 & $.1471^{* * *}$ & .0513 & $.1550^{* * *}$ & .0545 \\
\hline Ln \% black in 1990 & $.0322^{* *}$ & .0116 & $.0260^{*}$ & .0113 & $.0239^{*}$ & .0111 \\
\hline Ln \% black in 2000 & $.0783^{* * * *}$ & .0159 & $.0679^{* * * *}$ & .0149 & $.0655^{* * *}$ & .0149 \\
\hline$\%$ divorced & $-.0721^{* *}$ & .0297 & $-.0582^{*}$ & .0284 & $-.0626^{*}$ & .0285 \\
\hline$\%$ divorced $^{2}$ & $.0043^{* * * *}$ & .0013 & $.0038^{* * * *}$ & .0012 & $.0040^{* * * *}$ & .0012 \\
\hline \% Hispanic & $-.0108^{* * * *}$ & .0032 & $-.0097^{* * *}$ & .0031 & $-.0079^{*}$ & .0040 \\
\hline$\%$ Hispanic $^{2}$ & $.0002^{* * * * *}$ & .0001 & $.0002^{* * * *}$ & .0001 & $.0002^{* * * *}$ & .0001 \\
\hline Murder rate & -.0015 & .0019 & -.0020 & .0019 & -.0019 & .0019 \\
\hline Murder rate $^{2}$ & $.0001^{* *}$ & .0000 & $.0001^{* *}$ & .0000 & $.0001^{* *}$ & .0000 \\
\hline $\begin{array}{l}\text { Ln \% black } \\
\text { x segregation }\end{array}$ & $-.0021^{*}$ & .0012 & $-.0018^{*}$ & .0009 & $-.0017^{*}$ & .0010 \\
\hline South $\mathrm{x}$ segregation & - & - & $-.0055^{* * *}$ & .0016 & $-.0054^{* * *}$ & .0016 \\
\hline Ln poverty rate & - & - & - & - & .0020 & .0638 \\
\hline Ln crowding & - & - & - & - & -.0287 & .0364 \\
\hline Intercept & $5.3288^{* * * *}$ & .2156 & $5.2922^{* * * *}$ & .2041 & $5.3179^{* * * *}$ & .2909 \\
\hline $\mathrm{R}^{2}$ (corrected) & $.941^{* * * *}$ & & $.943^{* * * *}$ & & $.943^{* * * *}$ & \\
\hline AIC & -949 & & -964 & & -961 & \\
\hline $\begin{array}{l}{ }^{*} \leq .05 \\
\text { tailed } \\
\text { variab }\end{array}$ & $\begin{array}{l}\leq .01 \\
\text { ests on all c } \\
\text { es; standarc }\end{array}$ & $\begin{array}{l}001 \text { ( } \\
\text { effici } \\
\text { error }\end{array}$ & $\begin{array}{l}\text { Ird errors } t \\
\text { xcept the in } \\
\text { cted for he }\end{array}$ & $\begin{array}{l}\text { o th } \\
\text { nterc }\end{array}$ & $\begin{array}{l}\text { ht of coeffic } \\
\text { and period } \\
\text { dasticity). }\end{array}$ & $\begin{array}{l}\text { cients } \\
\text { l dum }\end{array}$ \\
\hline Note: & ity-years; & ff & n citv & $\mathrm{m}$ & shown & \\
\hline
\end{tabular}

beyond about the 87th percentile before this menace will produce additional police officers. Figure 1 provides a graphic depiction of this relationship using an augmented component plus residual plot (Mallows 1986) with cubic splines to estimate the nonlinear fit. ${ }^{6}$ The equivalent

6. Augmented component plus residual plots probably give the most accurate picture of departures from linearity with all other effects held constant. To isolate this nonlinear relationship, the graph in Figure 1 is based on the specification in Model 
inflection point for the relationship between the divorce rate and police strength is about 7.6 percent, or a value about equal to the 10 th percentile in the distribution of these city divorce rates. This association therefore becomes positive after divorce rates expand past a low threshold. Finally, the murder rates must grow to a point just below their mean (the mean murder rate is 16.1) or a rate of about 15.8 murders per 100,000 residents before the threat posed by increasingly substantial homicide rates starts to produce additional officers.

Figure 1. Hispanics in Cities and Police Officers per 100,000 (nonlinear fit estimated with a cubic spline; $\mathrm{N}=373$ city-years)

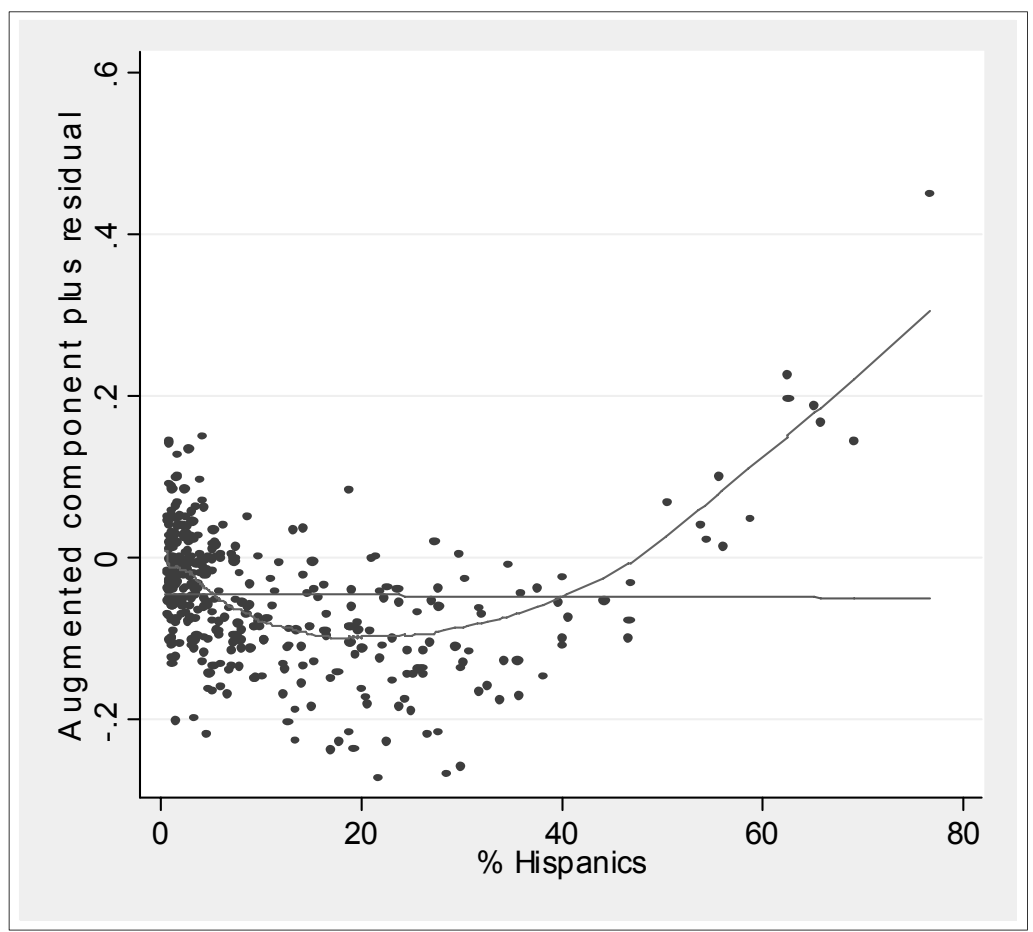

The strength of some of the linear relationships we have detected is not trivial. If we use the point estimates from Model 5 in Table 5, these values suggest that the elimination of a city manager will lead to about thirty-five additional police officers with all other explanatory variables held at their means. This addition represents about a 15 percent increase in the mean number of officers in these cities. ${ }^{7}$ With all of the other explanatory

5 without the squared percentage of Hispanics.

7. From 1980 to 2000 only two cities shifted from having or not having a city manager. 
variables held at their means in an equation not shown (in this equation we estimate the coefficients on all three period interactions rather than those on the main effect and two period interactions in the reported models), the point estimates suggest that a standard deviation increase in the percentage of blacks in 2000 should lead to roughly eighty additional police officers per 100,000 city residents.

Other plausible explanatory effects do not matter. Additional political or conflict effects such as the presence of a black mayor or the rate of black killings of whites do not explain the population standardized number of sworn officers. Alternative interactions such as those that assess Hispanic presence in the Southwest do not account for police strength. ${ }^{8}$ The extensive controls that include both the case- and time-specific dummy variables, the many explanatory factors that are held constant, the substantial explanatory power of these equations, and the results of the diagnostic tests all imply that this analysis has uncovered the primary explanations for the population corrected number of police officers in large U.S. cities since $1981 .^{9}$

Wooldridge, however, states that fixed-effects models will provide accurate estimates even if only a modest amount of overtime variation in an explanatory variable is present (2002). The cross-sectional variation is far more substantial than the over-time variation in this city manager variable. Because random-effects models capture both over-time and cross-sectional variation, we ran such models to see if random-effects findings about the influence of city managers differ from the fixed-effects results we report, but they do not. Although the point estimates become less substantial in the random-effects models, the negative coefficient on the city manager variable remains highly significant. The fixed-effects estimates we report probably are more accurate than the random-effects alternatives as Hausman tests support a fixed- rather than random-effects approach. Note as well that the city-specific dummy variables in the fixed-effects models have substantial explanatory power. Both findings suggest that omitted variable bias may be present if random-effects models are used instead of fixed-effects.

8. Although it is unlikely due to the 10 -year separation between cross-sections, serial correlation may be distorting the results. Most corrections for serial correlation in fixed-effects models remove the first cross-section. Such an analysis therefore would be restricted to cities in 1990 and 2000, but the statistical interactions we test require three periods. An alternative involves White period corrections to the standard errors (Lilien, 2004: 854). Because this method does not remove the first cross-section, when we re-estimate Models 5 and 6 using this procedure in Eviews 5.1, we find that the same explanatory variables are statistically significant.

9. Residuals graphed on the fitted (or the predicted) scores show the appropriate random cloud of points with no discernable patterns. More specific graphs of residuals on each of the explanatory variables give appropriate results as well, save for occasional heteroskedasticity, but we eliminate this threat to the standard errors with the White correction. New York had the largest (but still reasonable) leverage score, but, due to that city's extreme size, that finding enhances the plausibility of these models. The models reported in Table 5 pass the Ramsey-Reset test for specification error. A variety of other diagnostic tests and graphs suggest that no 


\section{CONCLUSIONS}

\section{FINDINGS}

Most of the theoretical expectations that motivated this analyses have been supported. Although our main theoretical impetus led to a focus on the relationships between minority threat and law enforcement strength, the results are informative about other interesting explanations as well. Save for the first less than complete model, the results always show that population matters. As theoretical considerations and prior findings suggest, this evidence indicates that studies that analyze smaller cities (Greenberg et al. 1985) are not as likely to find relationships between minority threat and police strength. Explanations involving social disorganization, however, had mixed effects. Probably due to the large number of domestic violence calls that police departments must handle, higher divorce rates after a minimal threshold evidently produce additional officers. Yet neither poverty nor within dwelling unit crowding explains the population corrected number of sworn officers.

Explanations borrowed from political science were corroborated as well. Many studies in this discipline have assessed the determinants of expensive public policies in U.S. states. These investigations almost always show that various measures of the tax base are strong determinants of such policies. Most of the coefficients reported in Tables 4 and 5 support this account: the real median family income indicator of a city's ability to support larger police departments was significant in four of the six models. This variable's weak effect in the final model probably is due the high correlation between median income and the percentage below the poverty line, but it is noteworthy that the addition of the poverty indicator had no effects on the significance of other coefficients in that model. The results, however, offer more consistent support for another perhaps more interesting political effect. Cities with appointed (rather than elected) city managers economize by hiring fewer officers. This strong relationship proved robust despite the formidable controls included in these two-way fixed-effects models. The findings also do not contradict neo-Marxist explanations derived from the literature on punishment as the results in all models suggest that cities with higher unemployment rates had more officers.

Although the aggregated property and violent crime rates did not explain variation in police strength, another more plausible crime related account was influential. After the association between the murder rates and police strength was specified so it could depart from linearity, another

serious statistical problems are present in sufficient strength to cast doubt on the findings. 
threshold relationship surfaces. Increasingly substantial murder rates produced additional police officers only if the murder rates almost reached the mean for all cities. This result makes sense for several reasons. First, the murder rate counts in the Uniform Crime Reports probably are more accurately measured than the other crime rates enumerated in this source. Second, it is plausible that politically influential citizens would make successful political demands for additional officers after this most serious of all crimes expanded past a threshold and therefore became increasingly conspicuous.

In light of the modest Hispanic populations in most U.S. cities but the large proportions in a few, we expected that the percentage of Hispanics would have to reach relatively high thresholds before the threat posed by this ethnic group would become substantial enough to produce additional officers. The results confirm this prediction as we find a positive relationship only after the percentage of Hispanics grew to beyond about 25.4 percent, or slightly more than five times its median. Although this ethnic threat explanation always accounts for police strength, its effects in most cities are weaker than racial threat. Perhaps such contrasting results should not be surprising in light of the fiercely divisive, sometimes lethal disputes about race throughout U.S. history together with the modest Hispanic populations in the great majority of U.S. cities. If this minority group continues to expand at its current rapid rate, but assimilation does not keep pace with the growth, subsequent studies may find that the relationship between the threat posed by Hispanic presence and police strength may become increasingly pronounced and different in shape.

The multiple findings about racial threat are not as simple. First, probably the most important finding concerns trends. The coefficients on the interactions with the period dummy variables show that the relationship between the percentage of African Americans and the per capita number of police officers has become stronger at least in the last two census years. We can conclude from such results that the law enforcement consequences of racial threat are not diminishing despite the purported progress in race relations since the civil rights era. The results instead suggest that the overall growth in mean department strength in these large cities since 1980 is at least partly due to the stronger relationships between racial threat and the expensive approach to social control provided by larger police departments.

The results indicate that other theoretically interesting contingent effects are present as well. The negative effects of the interaction between African American presence and residential segregation suggest that fewer police officers can be expected when a substantial black population is residentially isolated from urban areas where whites reside. It follows from all of these results that larger black populations evidently produce 
more police officers, but when such populations are geographically isolated from white neighborhoods, they probably become less threatening. Such reductions in racial threat lead to an expectation that the per capita number of police officers should be reduced in the most segregated cities with larger African American populations, and that, of course, is exactly what we find.

Finally, another contingent implication of the racial threat account is supported by the significant negative coefficients on the interaction between residential segregation and city location in the South. These results suggest that racial segregation sharply reduces police strength in this region, perhaps because the police in the South are more likely to assume that black citizens want less law enforcement. If this assumption is correct, officers would not be as likely to intervene in residentially segregated black neighborhoods (Wilson, 1971) and these cities would not need departments as large as cities with departments that aggressively police the ghetto.

\section{WIDER IMPLICATIONS}

In this study we have attempted to fill some important gaps in the literature on racial and ethnic threat and police strength. Because studies that assessed these threat effects were almost entirely cross-sectional and based on earlier data, recent shifts in the strength of threat accounts could not be assessed. Our approach probably produced findings that were more accurate in part because the statistical power necessary to detect interaction and nonlinear effects is enhanced when analyses are based on the larger number of cases made available by a panel design. And the twoway fixed-effects estimators we use let us test interactions with the period dummy variables to discover whether statistically significant fluctuations in the strength of the relationship between racial threat and police strength have occurred.

Such methodological refinements led to several other novel results that increase the plausibility of the racial threat account. First, we found several theoretically interesting nonlinear relationships that suggest that some explanatory variables must reach thresholds before they have effects on police strength. Second, one logical implication of the racial version of conflict theory is that in cities in which blacks are residentially separated from whites, majority white political demands for added police officers should be reduced. The supportive findings presented in this article also enhance the credibility of threat theory, especially when the relative number of police officers in large U.S. cities is at issue.

But several caveats are necessary. First, our models are not designed to explain the number of police on the street. Majority whites in cities with 
larger and more threatening minority populations can successfully express their preferences for additional officers. Yet they cannot control how these additional officers will be used. Citizens have little information about the division of labor within their city's department. In fact, a principal-agent relationship exists between citizens and their chief municipal political executive. Voters can support a political candidate who appears to be more likely than others to hire additional officers, but in most cities the mayor hires and fires the police executive who controls the department's division of labor. These agent decisions cannot be readily observed by principals who only can vote or not vote for the mayor. In emergencies, of course, specialist officers who normally would not be on the streets can be used for this purpose. The population-corrected number of sworn officers is therefore a good indicator of a department's total control capacity. And because there undoubtedly is a close association between the number police officers and the number of officers on the street, our results imply that explanations derived from threat theory should account for the number of officers on the street. Yet the need for three cross-sections imposed by our statistical models means that we must leave such questions about within department task allocations and the number of officers on patrol for another study. ${ }^{10}$

Second, one disadvantage of a city-level approach concerns the absence of explanatory factors that intervene between the determinants we can assess and police strength. Such a difficulty is present in almost all studies of the relationships between racial threat and criminal justice outcomes (and in most other studies as well). Direct indicators of white political activity due to minority threat cannot be incorporated into a multiperiod multicity analysis like this because such indicators are unavailable. Other findings, however, make threat-based assumptions about the intervening links between minority presence and police strength difficult to dispute. We know that larger black populations in cities (Liska et al., 1982) or in neighborhoods (Quillian and Pager, 2001) produce enhanced fear of crime even after the crime rates have been held constant. We also know that whites act politically at least in part due to such fears and to resentments against minority street criminals because expansions in minority populations produce increased white votes for anti-minority candidates (Giles and Buckner, 1993; Giles and Hertz, 1994). Note as well that such candidates are invariably strong supporters of harsh law and order measures. Both considerations strongly suggest that increases in the size of minority populations produce expansions in the number of police officers

10. Data on the internal allocation of police tasks apparently only exists for these or equivalent departments in 1990 and in 2000. Yet as we state in note 8, largely due to the interaction effects we test, our models require data from 1980 as well as cross-sections in the latter two census years. 
because threatened whites make successful demands for such an outcome. We can infer from these supplemental findings that the links between minority threat and police strength are probably due to the intervening explanatory factors spelled out in the politically informed version of threat theory we test in this study.

Probably the most important substantive conclusion, however, concerns the implications of the findings about racial effects. Robust results showing that there is an increasingly strong relationship between the presence of larger black populations and the number police officers in cities after many important explanatory effects have been held constant provide evidence about how important this minority threat explanation is, at least in a society with such a bitter history of racial conflict. In contrast to an optimistic view that racial threat is becoming less important, our findings suggest that this association is increasing in strength. The growth since 1980 in the association between African American presence and such an expensive form of social control suggests that the U.S. criminal justice system is still not color blind. Unfortunately, police strength in the United States continues to respond to racial and ethnic effects that should be irrelevant.

\section{REFERENCES}

Beckett, Katherine

1997 Making Crime Pay: Law and Order in Contemporary American Politics. New York: Oxford.

Blalock, Hubert

1967 Towards a Theory of Minority Group Relations. New York: Capricorn Books.

Blumer, Herbert

1958 Race prejudice as a sense of group position. Pacific Sociological Review 1:3-7

Bobo, Lawrence and Vincent Hutchings

1996 Perceptions of racial group competition: extending Blumer's theory of group position in a multiracial social context. American Sociological Review 61:951-72.

Chambliss, William J.

1964 A sociological analysis of the law of vagrancy. Social Problems 12:67-77.

Chiricos, Theodore G. and Miriam Delone

1992 Labor surplus and punishment: A review and assessment of theory and evidence. Social Problems 39:421-46. 
Chiricos, Ted, Kelly Welch and Marc Gertz

2004 Racial typification of crime and support for punitive measures. Criminology 42:359-89.

Cohen, Jacob, Patricia Cohen, Stephen D. West and Leona S. Aiken

2003 Applied Multiple Regression/Correlation Analysis for the Behavioral Sciences, 3rd ed. Hillsadale, NJ: Lawrence Erlbaum Associates.

Edsal, Thomas B. and Mary D. Edsal

1991 Chain Reaction: The Impact of Race, Rights, and Taxes on American Politics. New York: W. W. Norton.

Eitle, David, Stewart J. D'Alessio and Lisa Stolzenberg

2002 Racial threat and social control: a test of the political, economic, and threat of black crime hypothesis. Social Forces 81:557-76.

Ericson, Richard V.

1982 Reproducing Order: A Study of Police Patrol Work. Toronto: University of Toronto Press.

1989 Patrolling the facts: secrecy and publicity in police work. British Journal of Sociology 31:219-49.

Fosset, Mark A. and K. Jill Kiecolt

1989 The relative size of minority populations and white racial attitudes. Social Science Quarterly 70:820-835.

Garland, David

2000 The culture of high crime societies. British Journal of Criminology 49:347-375.

2001 The Culture of Control. Chicago: University of Chicago Press.

Giles, Michael W. and Melanie A. Buckner

1993 David Duke and black threat. Journal of Politics 55:702-713.

Giles, Michael W. and Kaenan Hertz

1994 Racial threat and partisan identification. American Political Science Review 88:317-6.

Greenberg, David, Ronald Kessler and Colin Loftin

1985 Social inequality and crime control. The Journal of Criminal Law and Criminology 76:684-704.

Huff, C. Ronald and John M. Stahure

1980 Police employment and suburban crime. Criminology 17:461-70.

Jackson, Pamela I.

1984 Opportunity and crime: a function of city size. Sociology and Social Research 69:172-93. 
1989 Minority Group Threat, Crime, and Policing. New York: Praeger.

Jackson, Pamela I. and Leo G. Carroll

1981 Race and the war on crime: the sociopolitical determinants of municipal police expenditures. American Sociological Review 46:290-305.

Jacobs, David

1979 Inequality and police strength: conflict theory and coercive control in metropolitan areas. American Sociological Review 44: 913-925.

1980 Dimensions of inequality and public policy in the states. Journal of Politics 42:291-306.

Jacobs, David and Jason T. Carmichael

2001 The politics of punishment across time and space: a pooled time-series analysis of imprisonment rates. Social Forces 80:6189.

Jacobs, David and Ronald Helms

1999 Collective outbursts, politics, and punitive resources: toward a political sociology of spending on social control. Social Forces 77:1497-1524.

Jacobs, David and Robert M. O'Brien

1998 The determinants of deadly force: a structural analysis of police violence. American Journal of Sociology 103:837-62.

Johnston, Jack

1984 Econometric Methods. New York: McGraw-Hill.

Johnston, Jack and John DiNardo

1997 Econometric Methods, 2nd ed. New York: McGraw Hill.

Kennedy, Peter

2003 A Guide to Econometrics. Cambridge, MA: MIT Press.

Kent, Stephanie L. and David Jacobs

2004 Social divisions and coercive control in advanced societies: law enforcement strength in eleven nations from 1975 to 1994. Social Problems 51:343-361.

Key, V. O. 1949 Southern Politics. New York: Vintage Books.

Levitt, Stephen D.

1997 Using electoral cycles in police hiring to estimate the effect of police on crime. American Economic Review 87:270-90. 
Lilien, David

2004 EViews 5 User's Guide. Irvine, CA: Quantitative Micro Software.

Liska, Allen E., J. J. Lawrence and M. Benson

1981 Perspectives on the legal order. American Journal of Sociology 87:412-26.

Liska, Allen E., J. J. Lawrence and A. Sanchirico

1982 Fear of crime as a social fact. Social Forces 60:760-71.

Liska, Allen E., Mitchell B. Chamlin and Mark D. Read

1985 Testing the economic and conflict models of crime control. Social Forces 64:119-38.

Lundman, Richard J. and Robert L. Kaufman

2003 Driving while black: Effects of race, ethnicity, and gender on citizen self-reports of traffic stops and police violations. Criminology 41:195-220.

Mallows, C. L.

1986 Augmented partial residuals. Technometrics 28:313-319.

Manning, Peter K.

1994 The police: symbolic capital, class, and control. In George S. Bridges and Martha Meyers (eds.), Inequality, Crime, \& Social Control. Boulder, CO: Westview Press.

Mayhew, Bruce H. and Roger L. Levinger

1976 Size and the density of interactions in human aggregates. American SociologicalReview 82:86-110.

Myrdal, Gunnar

1944 An American Dilemma: The Negro Problem and Modern Democracy. New York: Harper and Brothers.

Quillian, Lincoln and Devah Pager

2001 Black neighbors, higher crime? The role of racial stereotypes. American Journal of Sociology 107:717-767.

Rubenstein, Jonathan

1973 City Police. New York: Farrar, Straus, and Giroux.

Rusche, Georg and Otto Kirchheimer

1939 Punishment and Social Structure. New York: Russell and Russell. 
Sherman, Larry

1992 Attacking crime: Policing and crime control. In Michael Tonry and Norval Morris (eds.), Modern Policing. Chicago: University of Chicago Press.

Stolzenberg, Lisa, Stewart J. D'Alessio and David Eitle

2004 A multilevel test of racial threat theory. Criminology 42:673-98.

Stucky, Thomas D., Karen Heimer and Joseph B. Lang

2005 Partisan politics, electoral competition and imprisonment. Criminology 43:211-48.

Taylor, Marylee C.

1998 How white attitudes vary with the racial composition of local populations: Numbers count. American Sociological Review 63:512-535.

de Tocqueville, Alexis

1835/1948 Democracy in America. New York: Alfred A. Knopf.

Tolnay, Stewart E. and E. M. Beck

1996 A Festival of Violence: An Analysis of Southern Lynchings, 1882-1930. Urbana and Chicago: University of Illinois Press.

Tyler, Tom R. and Robert J. Boeckmann

1997 Three strikes and you are out, but why? Law and Society Review 31:237-265.

Weitzer, Ronald and Steven Tuch

2002 Perceptions of racial profiling: Race, class, and personal experience. Criminology 40:435-56.

Wilson, James Q.

1971 Varieties of Police Behavior. New York: Atheneum.

Wooldridge, Jeffrey M.

2002 Econometric Analysis of Cross Section and Panel Data. Cambridge, MA: MIT Press. 